\title{
声門閉鎖不全に対する声帯内ヒアルロン酸注入術の治療経験
}

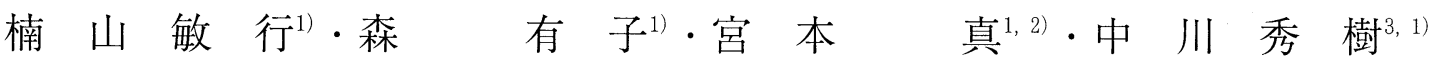 \\ 田村悦 代 ${ }^{4,1)} \cdot$ 新美成二11) 福田宏 之 ${ }^{1)}$
}

\section{A New Injection Laryngoplasty Using Hyaluronic Acid for the Treatment of Glottal Insufficiency}

\author{
Toshiyuki Kusuyama ${ }^{1)}$, Yuko Mori ${ }^{1)}$, Makoto Miyamoto, 2), \\ Hideki Nakagawa, ${ }^{3,}$, Etsuyo Tamura, 1), Seiji Niimi ${ }^{1)}$ \\ and Hiroyuki Fukuda ${ }^{1)}$
}

\begin{abstract}
Injection laryngoplasy is one of the typical remedies for the treatment of glottal insufficiency. In Japan, silicone, collagen, autologous fat, and calcium phosphate cement have been used as injectable materials. No material, however, can fulfill all the ideal conditions such as biocompatibility, nonabsorbability, non-migrating, and ready formulation for easy injection.

Hyaluronic acid (HA) is one component of the extracellular matrix that plays a key role in tissue viscosity, shock absorption, wound healing, and space filling. Research into the role of HA in laryngology indicates that it has profound effects on the structure and viscoelastisity of vocal fold.

Injection laryngoplasty using HA was performed on a patient with glottal insufficiency. HA was injected into the vocal folds using an oral laryngeal injection needle in conjunction with laryngeal electroendoscopic observation under local anesthesia. The injection procedure was accomplished safely and no acute foreign body reaction was observed. Evaluations were made from the patient' s subjective ratings, videostroboscopic examinations, and acoustical analyses. All of the postoperative results showed improvement when compared with preoperative status.

Injection laryngoplasty using HA could be one of the most suitable remedies for the treatment of glottal insufficiency.
\end{abstract}

Key words : 声帯内注入術, ヒアルロン酸, 声門閉鎖不全, 声带萎縮症

$$
\text { は じめに }
$$

声門閉鎖不全に対する代表的な外科的治療法の 1 つに声 帯内注入術がある。声帯内注入術における注入物質は Brünings がパラフィンを用いて ${ }^{1)}$ 以来さまざまなものが 用いられてきた。わが国においてはシリコンが頻用され $た^{2)}$ 後, 今日までアテロコラーゲン ${ }^{3 \sim 5)}$, 自家脂肪 ${ }^{6 \sim 10)}$, そしてリン酸カルシウム骨ペースト ${ }^{11 \sim 13)}$ 等が使用されて きた。 どの注入物質にも長所と短所があり，理想の注入物 質としての条件を満たしているとはいえない現状にある.

われわれは, 注入材料の新たな可能性として従来整形外 科領域で関節症治療などに用いられてきたヒアルロン酸に 注目した。ヒアルロン酸はグリコサミノグリカン（ムコ多
糖）の一種であり，関節，硝子体，皮膚，脳など広く体内 に分布する生体で最大の高分子ポリマーである ${ }^{14)}$.また, 喉頭では, 声帯粘膜固有層浅層に分布し, 声帯振動に最も 重要な役割を担うと考えられている ${ }^{15,16)}$. 今回, 声帯萎 縮症の症例に対し声帯内ヒアルロン酸注入術を施行し, 良 好な結果が得られたので考察を加えて報告する.

症例

患者：42歳，女性

主訴：嗄声

既往歴：特記すべき事なし.

現病歴：中学入学時より嗄声および発声困難感を認めて いた. 5 年前に某大学病院にてアテロコラーゲン声帯内注

1) 国際医療福祉大学東京ボイスセンター

2) 関西医科大学耳鼻咽喉科・頭頸部外科

3) 聖母病院耳鼻咽喉科

4 ) 東海大学医学部付属東京病院耳鼻咽喉科

1) Tokyo Voice Center, International University of Health and Welfare, Tokyo

2 ) Department of Otolaryngology-Head and Neck Surgery, Kansai Medical University

3 ) Department of Otolaryngology, Seibo International Catholic Hospital

4 ) Department of Otolaryngology, Tokai University School of Medicine, Tokai University Tokyo Hospital 
入術を 3 度施行するも満足な結果が得られなかった. 今回, インターネットなどの情報をもとに音声治療を希望し，当 センターを受診した。

初診時所見：喉頭内視鏡にて軽度の声帯萎縮を認めた。 喉頭ストロボスコピーでは声門閉鎖不全を認め, 粘膜波動 は規則性が障害され左右抒よび前後の位相差を認めた（図 1)。音声は二重声となっていた。

治療経過：患者の希望を優先し, Vocal Function Exercises 挍よびアクセント法を中心とした音声治療を施行 するも改善がえられなかった。 山王病院倫理委員会の審査 · 承認を経て, 声帯内ヒアルロン酸注入術を施行した。

声帯内ヒアルロン酸注入術：手術は局所麻酔下に経口的 に施行した。局所麻酔として，4\%塩酸リドカインを用い て咽頭喉頭に表面麻酔を行った，助手が鼻腔より挿入した 喉頭電子スコピーにより喉頭を観察した。注入材料は
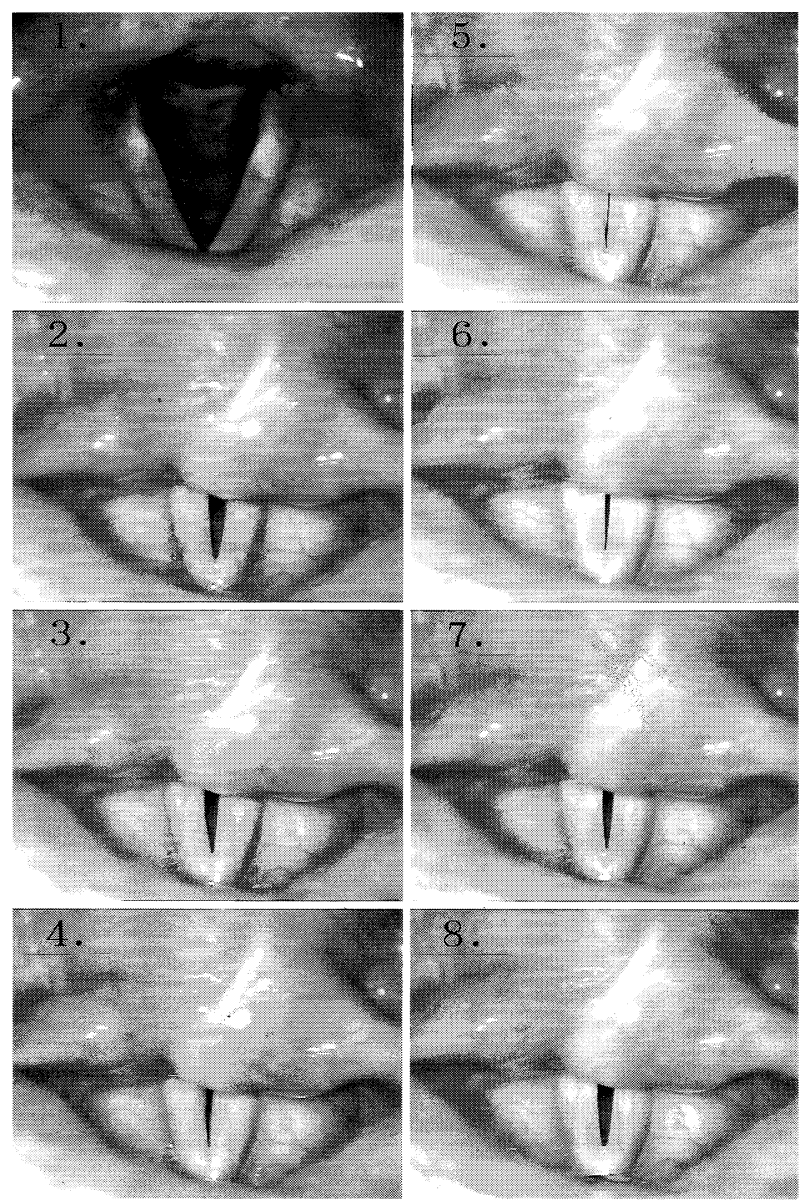

図1 初診時の喉頭ストロボスコピー所見 吸気時に軽度の声帯萎縮を認めた。喉頭ストロ ボスコピーでは声門閉鎖不全を認め, 粘膜波動 は規則性が障害され左右および前後の位相差を 認めた。

1. 吸気時, $2 \sim 8$. 声帯振動の 1 周期, 2 . Opened phase, 4. Closed phase, 8. Opened phase.

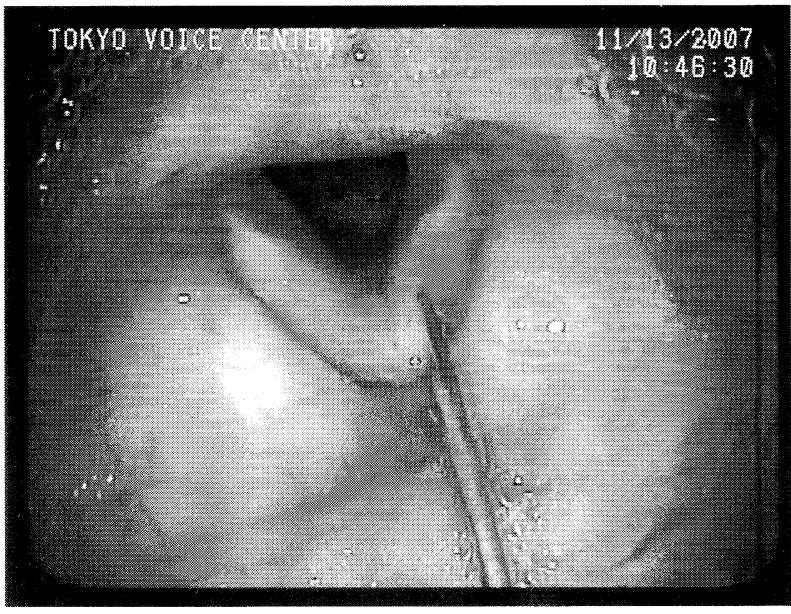

図 2 声帯内ヒアルロン酸注入術の実際 喉頭電子スコピーにより喉頭を観察し, 経口的 にヒアルロン酸を声帯内に注入した。
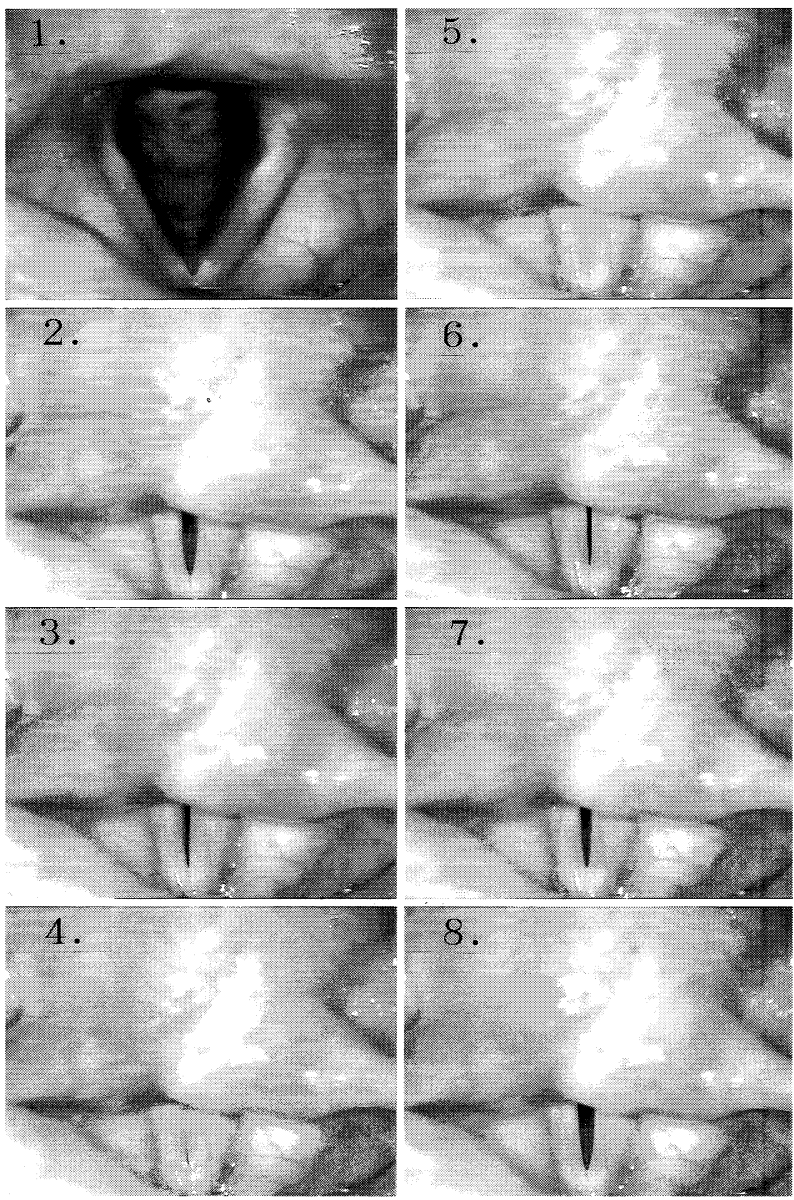

図 3 術後 1 週間の喉頭ストロボスコピー所見 声門閉鎖不全は改善し, 粘膜波動の規則性は回 復した。

1. 吸気時, $2 \sim 8$. 声帯振動の 1 周期, 2 . Opened phase, 4. Closed phase, 8. Opened phase. 
Anteis 社（スイス）製注入用ヒアルロン酸 Esthelis ${ }^{\circledR}$ Soft を使用した。ヒアルロン酸入りのシリンジに経口用喉頭注 入針 (永島医科器械) を装着し, 主に声帯粘膜固有層に注 入した（図 2)。声帯遊離縁がわずかに膨隆するレベルで 注入を終了した．今回の症例では左声带に $0.2 \mathrm{cc}$, 右声带 に $0.25 \mathrm{cc}$ の注入量であった。術後の沈黙期間は 3 日間とし た.

術後経過：術後 4 日の発声再開時より二重声は消失し, 発声困難感は軽減した. 術後 1 週間の喉頭ストロボスコピー 所見を示す (図 3)。声門閉鎖不全は改善し，声帯振動に 扔ける左右扔よび前後の位相差が消失し，規則性が回復し た。術後 3 ケ月の喉頭ストロボスコピーでは, 術後 1 週間 後と比較して声帯振動の振幅が増大し, 閉鎖期がさらに延 長する良好な結果となった (図 4). 術前後の音響分析結 果を示す (図 5)。術前と比較し術後 1 週間で $\mathrm{PPQ}, \mathrm{APQ}$ は減少し, $\mathrm{H} / \mathrm{N}$ は増加した。術後 3 ヶ月では全てのパラ メーターに扔いて更なる改善を認めた。
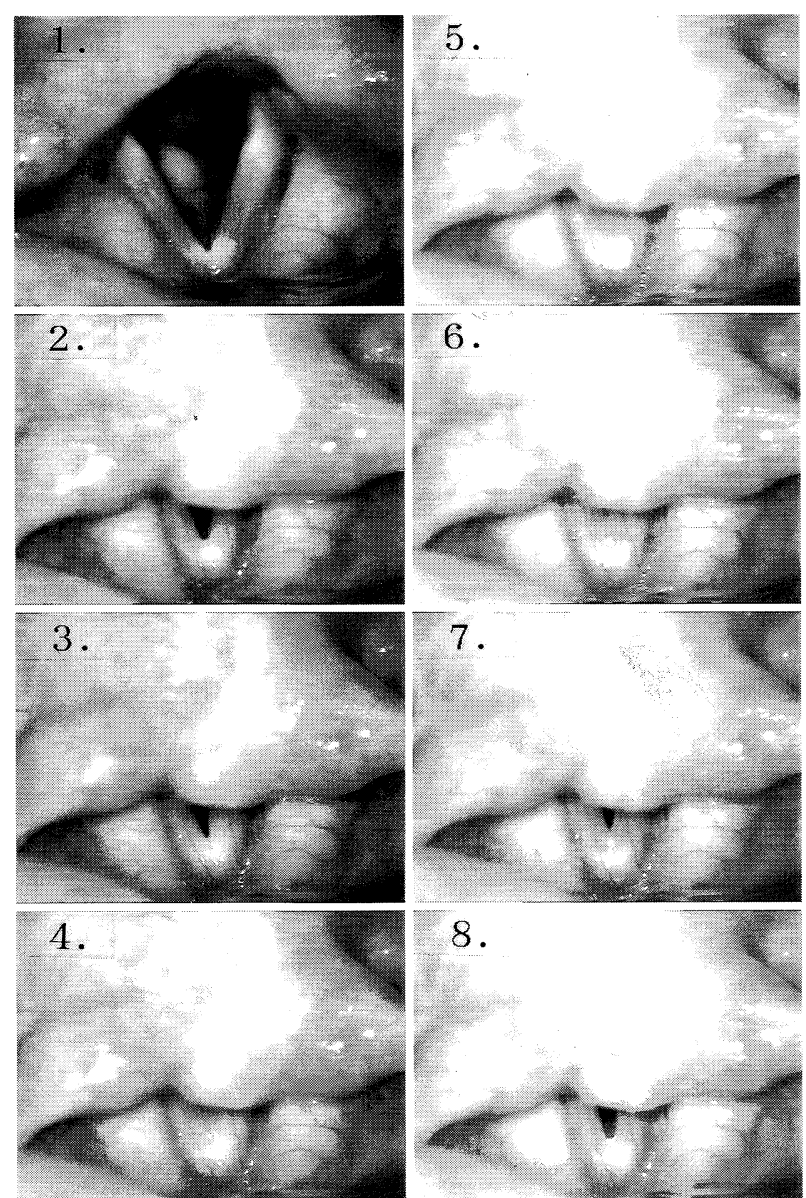

8.

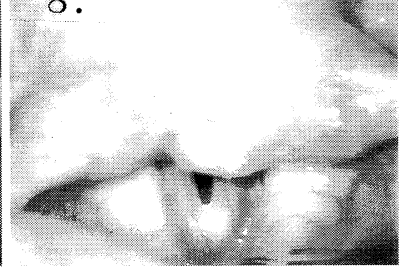

図 4 術後 3 ヶ月の㑨頭ストロボスコピー所見 術後 1 週間の所見と比較し, 声帯振動の振幅が 増大し，閉鎖期が延長した。

1. 吸気時, $2 \sim 8$. 声帯振動の 1 周期, 2 . Opened phase, 4. Closed phase, 8. Opened phase.

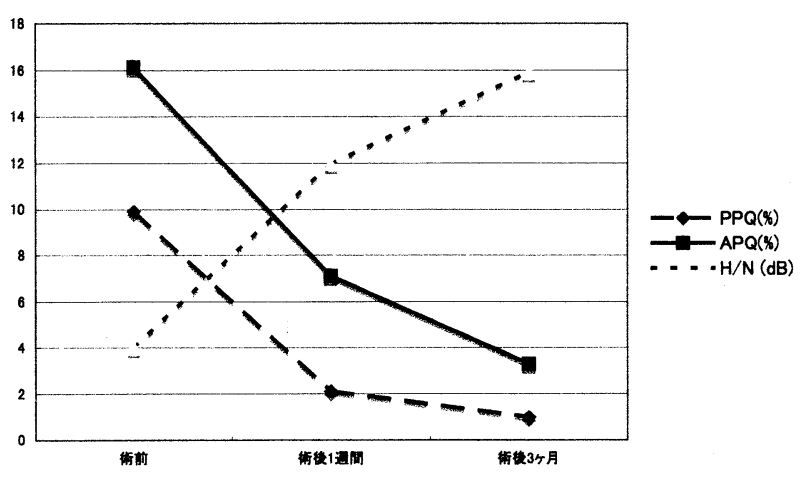

図 5 手術前後の音響分析結果 術前と比較し術後 1 週間で PPQ, APQ は減少 し， H/N は増加した，術後 3 ヶ月では全ての パラメーターで更なる改善を認めた。

\section{考}

察

声帯内注入物質について

声帯内注入術における注入物質は Brünings がパラフィ ンを用いて ${ }^{1)}$ 以来さまざまなものが用いられてきた。わが 国に拈いてはシリコンが頻用されてきだ2) が，後にヒト. アジュバント病の誘発 ${ }^{17)}$ 等の可能性が報告されたため声 帯内注入術は一時施行困難な状況となった。しかしながら 最近新たな注入物質が開発され，注入術は再び注目されつ つある。今日までアテロコラーゲン ${ }^{3 \sim 5)}$, 自家脂肪 ${ }^{6 \sim 10)}$, そしてリン酸カルシウム骨ペースト 11 13) 等が用いられて きた。さらには分子生物学的アプローチとして増殖因子の 注入に関する研究 ${ }^{18)}$ もなされている。 どの注入物質にも 長所と短所があり，組織反応が少なく，注入後も吸収され ず注入部位に留まり，注入が容易でかつその準備が簡便で あるといった理想的な注入物質はいまだ存在しない. 今回, われわれは，整形外科領域や美容外科領域で用いられてい るものの, 声帯内注入に関しては海外での報告は数少な く19 22)，国内では未だ報告されていないヒアルロン酸に 注目した。

\section{ヒアルロン酸について}

ヒアルロン酸は N アセチル D グルコサミンと D グルク ロン酸が繰り返し連結された直鎖状グルコサミノグリカン (ムコ多糖) であり，生体で最大の高分子ポリマーである。 大きな特徴は水和力や粘弾性，そして水溶液中でとりうる 可変的な網目構造をもつことにある。また，細胞移動や分 化，増殖などの生理的物理的現象にも関わる。単純な構造 でありながらこのような幅広い特徵をもつことはターンオー バーの過程で数1000から1000万 Da にまで及ぶ多様な分子 量をとることに由来するとされる ${ }^{14)}$ 。ヒアルロン酸は関節, 硝子体，皮膚，脳など広く体内に分布し，喉頭においても 声帯粘膜固有層浅層内に広く分布する ${ }^{15)}$.声帯内のヒアル ロン酸を酵素消化し声帯の粘弾性を検討した研究によりヒ アルロン酸は声帯振動に最も重要な役割を担う細胞外マト 
リックスと考えられている16).

声帯内ヒアルロン酸注入術について

声帯内ヒアルロン酸注入術に関する基礎研究として Hallen らはウサギを用いた声帯内注入術後の組織学的検 討を行い, 同術式の良好な持続性および低侵襲性を報告し た ${ }^{19)}$. Dahlqvist らはコラーゲン，テフロンと比較してヒ アルロン酸注入術がレオロジー学的に最も良好な結果をも たらし，正常声帯に近似していると報告した ${ }^{20)}$. 臨床研究 として Hertagårdらは喉頭麻盘または声带萎縮症症例に 対してヒアルロン酸またはコラーゲンを声帯内に注入する プロスペクティブスタディーを施行した．喉頭ストロボス コピーおよび音声機能検査を用いた検討によりヒアルロン 酸注入症例が有意に良好であったと結論した ${ }^{21,22)}$. 以上 の報告をもとに今回声带萎縮症症例に対し声帯内ヒアルロ ン酸注入術を施行し，良好な結果を得るに至った。

今回，注入材料として Anteis 社製 Esthelis ${ }^{\circledR}$ Soft を使 用した。注入用ヒアルロン酸製剤の中では最も軟らかいも のの 1 つで, 目尻のしわなど, 真皮浅層中間層への注入材 料としてょり軟らかい補正を目的に開発，製造された 20 $\mathrm{mg} / \mathrm{ml}$ の注入用ヒアルロン酸製剤である。主に声帯粘膜 固有層に注入し，術後 1 週間の喉頭ストロボスコピー所見 および音響分析における全てのパラメーターにおいて術前 と比較し著明な改善を認めた。当ヒアルロン酸製剤が声帯 粘膜波動に適した物性であり，振動部声带のボリュームロ スの補正として有用な注入材料であることを示唆するもの と思われる，当ヒアルロン酸製剂は従来の注入用ヒアルロ ン酸製剤と比較して，1）バイオテクノロジーを用いた非 動物性発酵による精製であるため感染性の心配がなくまた アレルギー反応が極めて起こりにくい，2）粒子を形成し ない単一形状ゲル状の物性であり, かつ架橋密度を高密度 の部分と低密度の部分を混在させることにより注入後の不 均一性, 注入時の抵抗性と持続効果の問題点を改善してい る，3）商品は注入用シリンジ仕様のため操作が極めて簡 便である, などの特徵を持ち, 新たな声帯内注入材料とし て今後期待されうるものと思われる.さらに, 術後 1 週間 後と比較し 3 ケ月後に全てのパラメーターにおいて更なる 改善を認めた. Hallen らはウサギの声帯内ヒアルロン酸 注入術後の組織学的検討を行い, 血管新生, 線維芽細胞, コラーゲン, 内因的ヒアルロン酸の出現などによる結合組 織の新たな形成は月数が増すにつれて増加を認めたと報告 した ${ }^{19)}$. 本症例においても同様の反応をみた可能性が示唆 されるが症例の蓄積が必要であることは言うまでもない.

$$
\text { ま と め }
$$

声門閉鎖不全症例に対し声帯内ヒアルロン酸注入術を施 行し，良好な結果が得られた 1 症例を報告した。

ヒアルロン酸は分子量や濃度, 粒子の大きさなどにより 粘弾性や持続性が異なるため選択に慎重を要するが, 振動 部声帯のボリュームロスに対する注入材料として，その有
効性と安全性より現時点で最良の物質の一つと考えられた. 今後もさらに症例を重ね, その有用性を検証したい.

\section{参 考 文 献}

1) Brünings $W$ : Uber eine neue Behandlungs Methode der Rekurrenslahmung. Verhandl Ver Deutsch Laryngol 18: 93 98, 1911.

2)福田宏之：注入用 silicone による vocal rehabilitation. 日耳鼻 $73: 1506 \sim 1526,1970$.

3) Ford CN, Bless DM : Clinical experience with injectable collagen for vocal fold augmentation. Laryngoscope 96:863〜869, 1986.

4）湯本英二, 岡村和憲, 川村裕二ほか：片側反回神経 麻痺に対するアテロコラーゲン声帯内注入療法. 日 気食会報 $39: 271 \sim 274,1988$.

5）木村美和子, 二藤隆春, 今川 博ほか：一側声帯麻 舫症例に対する声帯内コラーゲン注入術長期経過の 検討。日気食会報 $59: 304 \sim 310,2008$.

6) Mikaelian DO, Lowry LD, Sataloff RT : Lipoinjection for unilateral vocal cord paralysis. Laryngoscope 101：465～468, 1991.

7）小川佳伸, 松永 喬, 古川太一ほか：自家脂肪注入 による声帯麻痺治療例．耳鼻臨床８7：1257～1262， 1994.

8）梅野博仁，千年俊一，白水英貴ほか：病因を考慮し た声帯内注入術。日気食会報 $53: 113 \sim 118,2002$.

9) Sato K, Umeno $H$, Nakashima $T$ : Histological investigation of liposuctioned fat for injection laryngoplasty. Am J Otolatyngol 26:219 225, 2005.

10）田村悦代, 福田宏之, 楠山敏行ほか：煩部脂肪体を 用いた声带内自家脂肪注入術の 1 例. 喉頭 18 : 124 126, 2006.

11）塩谷彰浩, 池田麻子, 富藤雅之ほか：リン酸カルシ ウム骨ペースト $\left(\mathrm{BIOPEX}^{\circledR}\right)$ を用いた声帯内注入 術. 喉頭 $16: 127 \sim 130,2004$.

12) Ikeda A, Shiotani A, Mori Y et al : Suitability of calcium phosphate cement for injection laryngoplasty in rabbits. ORL J Otorhinol 68 : 103 109, 2006.

13）大久保啓介, 斎藤康一郎, 藤峰武克ほか：声帯内 $\mathrm{BIOPEX}^{\circledR}$ 注入術. 音声言語医学 $48(2) ： 171 \sim 177$, 2007.

14）井上紳太郎, 佐用哲也 : ヒアルロン酸のターンオー バーと疾患. 生化学 77(9)：1152〜1164, 2005.

15) Ward PD, Thibeault SL, Gray SD : Hyaluronic acid: its role in voice. J Voice $16(3): 303 \sim 309$, 2002.

16) Chan RW, Gray SD, Titze IR : The importance of hyaluronic acid in vocal fold biomechanics. 
Otolaryngol Head Neck Surg 124:607 614, 2001.

17) van Nunen SA, Gatenby PA, Basten A : Postmammoplasty connective tissue disease. Arthritis Rheum 25:694 697, 1982.

18）平野 滋：声带粘膜の細胞外マトリックスに対する 分子生物学的アプローチ. 喉頭 $18: 1 \sim 9,2006$.

19) Hallen L, Johansson C, Laurent $C$ : Cross-linked Hyaluronan (Hylan B Gel): a New injectable remedy for treatment of vocal fold insufficiencyan animal study. Acta Otolaryngol 119: 107 111, 1999 .

20) Dahlqvist ̊, Gärskog $\mathrm{O}$, Laurent $\mathrm{C}$ et al : Viscoelasticity of rabbit vocal folds after injection augmentation. Laryngoscope $114: 138 \sim 142$,
2004.

21) Hertagård S, Hallen L, Laurent C et al : Crosslinked hyanuronan used as augmentation substance for treatment of glottal insufficiency: safety aspects and vocal fold function. Laryngoscope 112: 2211 2219, 2002.

22) Hertagård S, Hallen L, Laurent $C$ et al : Crosslinked hyanuronan versus collagen for injection treatment of glottal insufficiency: 2-year followup. Acta Otolaryngol 124: 1208 1214, 2004.

別刷請求先 $\bar{\top} 107-0052$ 東京都港区赤坂 8-10-16

山王病院内 国際医療福祉大学 東京ボイスセンター 楠山敏行 